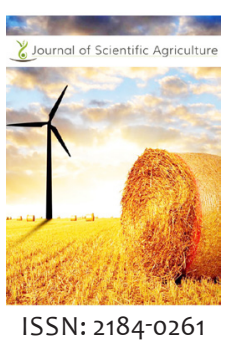

Received: February 19, 2019 Accepted: April 02, 2019 Published: April 06, 2019

*Corresponding Author: Muhammad Arshad Ullah Email: arshadullah1965@gmail. com

\section{Adaptability studies of garlic (Allium sativum) advanced lines}

\author{
Asfand Raheel', Hidayatullah², Raheel Babar4, Muhammad Arshad Ullah*, \\ Ali Zaffar', Maouz Iqbal'
}

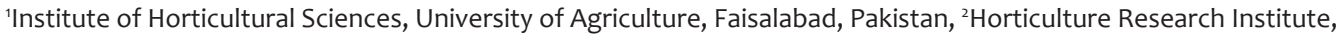
National Agriculture Research Center (NARC), Islamabad 45500, Pakistan, ${ }^{3}$ Land Resources research Institute, National Agricultural Research Centre, Islamabad 45500, Pakistan, ${ }^{4}$ Forestry, Range, Watershed and Wildlife management, Baluchistan Agriculture College, Quetta, Pakistan

\begin{abstract}
The purpose of this research was to identify the most desirable verities adopted in different environmental conditions of the country. Five garlic advance line; NARC Garlic-1, NARC Garlic-3, NARC Garlic-4, NARC Garlic-5 along with 'Lehsan Gulabi' as check were evaluated at different locations along with NARC, Islamabad. Different morphological parameters; plant height, plant girth, leaf number per plant and leaf width were studied at four different growth stages NARC Garlic-l performed better as compared other advance lines and control tested.
\end{abstract}

KEYWORDS: Adaptability, garlic, Allium sativum, advance lines

\section{INTRODUCTION}

The Garlic $(2 \mathrm{~N}=16)$ (Allium sativum) have its place to the family amaryllidaceae. It belongs to known Allium genus which contains 600 species [1]. Garlic has advanced nutritive values than other bulbous crops. It is ironic in protein, potash, phosphorous, magnesium, calcium and carbohydrates. The new and fresh peeled garlic comprise approximately $0.8 \%$ fibre, $63 \%$ water, $7 \%$ protein, $28 \%$ carbohydrate, $0.2 \%$ fat and a great number of sulphur compounds, which subsidize to the pungent taste of garlic [2]. Garlic is grown worldwide but as usual, China is the largest producer of garlic bookkeeping for $75 \%$ of world production. India stands second in area and production in the world later China. On an average, in India, garlic is cultivated on 2.01 lac hectares producing 10.58 lac million tones with an average productivity of 5.27 tha $^{-1}[3]$. This Study concerning the regular developmental growth of the selected garlic lines and are worth in development of pure garlic by improving the practices. Cultivars of Garlic either local or foreign are diverse in their development and yield potentially [4]. When garlic cultivars grown under different and similar environmental circumstances were, vary their traits including their morphology like the number of leaves, date of blossom, final girth and length of stem and their flowering ratio. The basic chemical component of bulbs of garlic was differentiated according to their types [5]. Garlic as an asexually propagated crop expresses extreme structural variations [6-7] and grown since at least 5000 years and it is thought started in Central Asia as garlic wild cultivation.
Allium species shows highly diversification from Central Asia, Pakistan to Mediterranean basin [8]. Globally, garlic is thought an important source of medicine for gastronomic problems [9]. It is highly crucial to know local populations demands keeping in view the relationships between yield components and in accordance with specific climatic factors [10-11]. Thus the present work aimed to the study the developmental changes in growth and yield potential of garlic advance lines in comparison to the local cultivar.

\section{MATERIAL AND METHODS}

The experiment was carried out at the experimental field of Directorate of vegetable, DHR\&D, National Agriculture Research Center (NARC), Islamabad during 2015-2016. Experimental site is located at longitude $73.08^{\circ}$ east and latitude $33.42^{\circ}$ north on global scale. Elevation of site was $683 \mathrm{msl}$ (mean sea level). Cloves of all garlic lines were planted on 21 October, 2015 on flat land. Single cloves are used for sowing. Cloves were treated with fungicide. Before planting land was prepared by ploughing and planking and FYM was also mixed. Adaptability trail was planted in NARC, Islamabad. Four garlic cultivars (NARC Garlic-1, NARC Garlic-3, NARC Garlic-4 and NARC Garlic-5) with Lehsan Gulabi as check were planted using Randomized Complete Block Design (RCBD) with three replications. Row to Row and Plant to Plant distances were maintained at $25 \mathrm{~cm}$ and $10 \mathrm{~cm}$, respectively. Cloves were treated with fungicide before sowing. After sowing, first irrigation

Copyright: $\odot$ The authors. This article is open access and licensed under the terms of the Creative Commons Attribution License (http://creativecommons.org/licenses/by/4.0/) which permits unrestricted, use, distribution and reproduction in any medium, or format for any purpose, even commercially provided the work is properly cited. Attribution - You must give appropriate credit, provide a link to the license, and indicate if changes were made. 
Table 1: Morphology comparison of Garlic (Allium sativum) advance lines

\begin{tabular}{|c|c|c|c|c|c|c|c|c|c|c|c|c|c|c|c|c|c|}
\hline \multirow[t]{2}{*}{ Varieties } & \multirow[t]{2}{*}{ Survival (\%) } & \multicolumn{4}{|c|}{ Plant height } & \multicolumn{4}{|c|}{ \# of leaves } & \multicolumn{4}{|c|}{ Plant girth } & \multicolumn{4}{|c|}{ Leaf width } \\
\hline & & 1 & 2 & 3 & 4 & 1 & 2 & 3 & 4 & 1 & 2 & 3 & 4 & 1 & 2 & 3 & 4 \\
\hline$V_{1}$ & $85.0^{\mathrm{a}}$ & $30.1^{b}$ & $38.9^{b}$ & $76.9^{\mathrm{a}}$ & $61.8^{b}$ & $6.4^{a}$ & 7.5 & 8.5 & 8.8 & $4.8^{a}$ & 5.4 & 9.1 & 6.3 & 2.6 & $3.2^{\mathrm{a}}$ & $3.3^{\mathrm{a}}$ & $3.2^{\mathrm{a}}$ \\
\hline$V_{2}$ & $76.7^{\mathrm{ab}}$ & $34.6^{b}$ & $43.4^{b}$ & $49.5^{b}$ & $62.4^{b}$ & $5.9^{\mathrm{ab}}$ & 7.1 & 8.1 & 8.3 & $4.0^{b}$ & 4.5 & 4.8 & 7.9 & 2.0 & $2.4^{b}$ & $2.6^{\mathrm{b}}$ & $2.4^{b}$ \\
\hline$V_{3}^{2}$ & $54.2^{b}$ & $33.3^{b}$ & $41.7^{\mathrm{b}}$ & $53.5^{b}$ & $61.9^{\mathrm{b}}$ & $5.8^{b}$ & 6.9 & 8.1 & 9.1 & $3.8^{b}$ & 4.2 & 4.6 & 4.9 & 1.9 & $2.4^{b}$ & $2.7^{\mathrm{b}}$ & $2.4^{b}$ \\
\hline$V_{4}^{3}$ & $91.7^{\mathrm{a}}$ & $34.9^{b}$ & $41.0^{b}$ & $49.6^{b}$ & $63.7^{\mathrm{b}}$ & $5.9^{\mathrm{ab}}$ & 7.0 & 16.3 & 9.0 & $3.6^{\mathrm{b}}$ & 7.2 & 5.0 & 5.1 & 2.0 & $2.5^{\mathrm{b}}$ & $2.6 b$ & $2.5^{b}$ \\
\hline$V_{5}$ & $82.5^{\mathrm{a}}$ & $65.1^{b}$ & $69.5^{a}$ & $76.9^{a}$ & $81.6^{a}$ & $6.1^{\mathrm{ab}}$ & 7.2 & 8.2 & 9.0 & $3.9^{\mathrm{b}}$ & 4.4 & 6.9 & 4.6 & 2.7 & $2.2^{b}$ & $2.6^{\mathrm{b}}$ & $2.2^{b}$ \\
\hline LSD & 27.1 & 5.2 & 7.5 & 18.7 & 15.6 & 0.6 & NS & NS & NS & 0.5 & NS & NS & NS & N.S & 0.6 & 0.5 & 0.6 \\
\hline
\end{tabular}

Means with different letters are significantly different at $5 \%$ level of probability

$V_{1}=$ NARC Garlic-1. $V_{2}=$ NARC Garlic-3, $V_{3}=$ NARC Garlic- 4, $V_{4}=$ NARC Garlic- 5, $V_{5}=$ LehsonGulabi $1=125$ Days After Planting, $2=140$ Days After Planting, $3=155^{2}$ Days After Planting , $4=170$ Days After Planting

was done immediately. First Hoeing and Weeding were done at November 19, 2015. NPK were applied. Water application through flood irrigation by tube well water and water tanks were used. Rain water also a great source of irrigation. Crop mainly remains depended on rain water however; time to time it was also irrigated on need basis. First irrigation was done at the time of planting on $21^{\text {st }}$ of October. Flood irrigation is applied through water channel. On $29^{\text {th }}$ of November a second irrigation was applied. Third irrigation was applied on $4^{\text {th }}$ of December with urea. Last irrigation was applied on $8^{\text {th }}$ of April. Hoeing and weeding were done at one month interval. First at 19 November, 2015. Then second at $8^{\text {th }}$ of December. Third hoeing is at $7^{\text {th }}$ of January then $6^{\text {th }}$ of February. From onwards, hoeing is done at $7^{\text {th }}$ of March then last at $8^{\text {th }}$ of April before irrigation. The amount of fertilizer applied to the field of garlic during research time period were $1 \mathrm{~kg}$ of urea mixed with $1 \mathrm{~kg}$ of sulphate of potash (SOP). $5 \mathrm{~kg}$ fertilizer was applied to the all plots of garlic advanced lines. Four plants per treatment per replication were selected for data recording. Observations were compiled after taking their averages. The data were recorded on the Following Parameters: survival percentage, plant height, \# of leaves per plant, leaves width, plant girth. The data obtained were subjected to statistical analysis using the STATISTIX statistical software (Version 8.1) and the mean values were compared using Least significant difference (LSD) multiple range test $P: 0.5 \%$.[12].

\section{RESULTS AND DISCUSSION}

A significant difference was recorded among garlic advance lines tested at NARC. Maximum survival was recorded in NARC Garlic-1, NARC Garlic-5 and Lehsan Gulabi (check) ranging $82-91 \%$. However lowest percentage of plant survival $54 \%$ was recorded in NARC Garlic-4 (Table-1). Hot and warm climate in India and Bangladesh caused yield reduction of locally garlic cultivars [13]. Al-Zahim et al. [14] grown 27 chosen discreetly garlic genotypes under the similar environment conditions for several years, three were selected considering morphological characters. Quantitative distinctiveness are expected to be prejudiced by escalating environment [15].All garlic advance lines had shown significant difference regarding plant height throughout their life cycle. However, growth rate was different at different stages or plant age. After germination of garlic cloves at 120 days the maximum plant height was recorded (62.40) in genotype YamunaSafed-3 (G-282) trailed by Yamuna Safed - 1
(G-1) $60.15 \mathrm{~cm}$. The minimum plant height was documented (54.77) in Madrasi Local trailed by NHRDF - 1, Deoria $(56.00 \mathrm{~cm})$ and Gyanpur, Local Collection and SRD Nagar $(56.08 \mathrm{~cm})$. These outcomes are in agreement with conclusions of [16-17] who assessed the performance of garlic genotypes for height of plant. Overall Lehsan Gulabi used as check produced taller plants as compared to all advance lines tested except at the age of 155 days after planting where NARC Garlic-l along with Lehsan Gulabi produced more taller plants compared to other advance lines (Table-1).

Garlic is a clonally propagated species, which may reduce variation hence number of clusters should be few [15].Slightly significant differences were recorded among different garlic advance lines only at 125 days after planting. Maximum number of leaves per plant was recorded from NARC Garlic-l and minimum for NARC Garlic -4. Rest of two advance lines and Lehsan Gulabi (used as check) showed at par result with the maximum and minimum limits 5.86-6.13 (Table-1). On comparison of number of leaves of garlic advance lines at a particular growth stage, it is evident from the table 1 that pattern remain same up to 155 days after planting. However, after 15 days more the sequence among the advance lines with regard to number of leaves per plant changed. Figure indicated that NARC Garlic-3 produced less number of leaves and NARC Garlic-l was found at the top as compared to other advance lines and control.

Plant girth also showed similar pattern as number of leaves. A non-significant difference was recorded at 140, 155 and 170 days after planting among garlic advance lines. However, at initial stage of 125 days after planting maximum plant girth was recorded by NARC Garlic-l followed by all other advance lines and check and no significant difference recorded among these garlic advance lines (Table-1). A great variation with regard to plant girth was found among all advance lines at all growth stages. NARC Garlic-l showed maximum plant girth at 125 and 155 days after planting while NARC Garlic-3 at 170 days after planting. However, at 140 days after planting no advance lines could exceed from control with regard to plant girth (Table-1)

Similar leaf width was recorded among garlic advance lines at initial growth stages i.e. 125 days after planting. However, with the older plant i.e. at all other stages $(140,155$ and 170 days after planting) all lines behave slightly different with each other. Maximum leaf width was recorded by NARC Garlic-l at all the later stages (Table-1). 


\section{CONCLUSION}

Different morphological parameters; plant height, plant girth, leaf number per plant and leaf width were studied at four different growth stages. NARC Garlic-l performed better as compared other advance lines and control tested.

\section{REFERENCES}

1. Meer QP, Botha JL, Galmarini CR. Old and new crops within edible Allium. Proceedings of the first international symposium on edible Alliaceae. Acta Horticulturae. 1997; 433:17-31.

2. Rabinowitch $\mathrm{H}$. and Currah L. Allium crop science: recent advances. CABI, Int. Wallingford United Kingdom. 2002; 616 pp.

3. Anonymous. Horticulture Division, Ministry of Agriculture, Government of India, New Delhi. 2012.

4. Walters SA. Production method and cultivar effects on garlic overwintering survival, bulb quality and yield. Horticulture Technology. 2008: 18(2): 286-289

5. El-Zemaity MS, Salama SI, Ahmed AA, Mahmoud ER. Some factors affecting the susceptibility of four stored garlic cultivars to infestation with Cryptoblabesgnidiella milliere. Arab Univ. J. Agric. Sci., 2009; 17: 185-192.

6. Bradley KF, Rieger MA, Collins GG. Classification of Australian garlic cultivars by DNA finger printing. Aust J. Exp. Agri. 1996; 36: 613-618.

7. Pooler MR, Simon PW. Characterization and classification of isozyme and morphological variation in a diverse collection of garlic clones. Euphytica. 1993; 68: 121-130.

8. Fritsch RM, Friesen N. Evolution, domestication and taxonomy. In: Rabinowitch H.D. and Currah L. (eds), Allium Crop Science: Recent Advances. CABI Publishing, 2002; 65-30

9. Simon PW. The origins and distribution of garlic: How many garlics are there? USDA, ARS, Vegetable Crop Research Unit, Department of Horticulture, University of Wisconsin, Madison, WI 53706. 2001.

10. Dhotre M, Allolli TB, Athani SI, Halemani LC. Genetic variability, character association and path analysis studiesin KharifOnion (Allium. cepa L.), Asian J. Hort.2010; 5:143-146.

11. Asohk P, Sasikala K, Pal N. Association among growth characters, yield and bulb quality in Onion, Allium cepa L. Inter. J. Farm Sci. 2013: 3:22-29.

12. Steel RGD, Torrie JH.Principles and Procedure of Statistics. McGraw Hill Book Co., Inc. Singapore, 1997: 173-177.

13. Singh MC, Tiwari RS. Yield and quality attributes of garlic (Allium sativum L.) accessions. Haryana J. Hort. Sci. 1995; 24: 46-49.

14. Al-Zahim M, Newbury HJ, Ford-Lloyd BV.Classification of genetic variation in garlic Allium sativum L. revealed by RAPD. Hort. science 1997: 32: 1102-1104.

15. Menezes-Sobrinho JA, de Charchar JM, Aragao FAS.Morphological characterization of garlic germplasm by multivariate analyses of principal components and canonic variables. Horticultura Brasileira. 1999: 17: 96-101.

16. Tiwari RS, Ankur Agrawal, Sengar SC, Agrawal A. Performance of garlic genotypes under Tarai Region of Uttaranchal. Progress Hort. 2017; 34(2):183-186

17. Futane NW, Jogdande ND, Gonge VS, Warade AD, Khandagal SS Evaluation of garlic genotypes. Int., J. Agric. Sci., 2017; 2(1):2-5. 